\title{
Growth and Yield of Wheat (Triticum aestivum L.) Varieties as Influenced by Different Sowing Dates under Bastar Plateau Zone of Chhattisgarh
}

\author{
Anil Kumar Netam ${ }^{1 *}$, Upendra Kumar Nag ${ }^{2}$ and Chainu Ram Netam ${ }^{3}$ \\ ${ }^{1}$ AICRP on IFS - On Farm Research, IGKV, Krishi Vigyan Kendra, \\ Kanker, Chhattisgarh, India \\ ${ }^{2} I G K V$, Krishi Vigyan Kendra, Kanker, Chhattisgarh, India, \\ ${ }^{3} I G K V$, College of Agriculture \& Research Station, Marra, Chhattisgarh, India, \\ *Corresponding author
}

\section{A B S T R A C T}

A field experiment was conducted during the Rabi season of 2016-17, at the Instructional Farm, Shaheed Gundadhoor College of Agriculture \& Research Station, Kumhrawand, Jagdalpur District- Bastar (Chhattisgarh). The soil of experimental site was sandy loam; it was low in organic carbon $(0.41 \%)$ and available nitrogen $\left(228.90 \mathrm{~kg} \mathrm{ha}^{-1}\right)$ and

\section{Keywords}

Sowing dates, wheat, varieties, growth, crop stages, yield, economics

\section{Article Info}

\section{Accepted:}

18 May 2020

Available Online:

10 June 2020 medium in available phosphorus $\left(12.26 \mathrm{~kg} \mathrm{ha}^{-1}\right)$ and potassium $\left(286.25 \mathrm{~kg} \mathrm{ha}^{-1}\right)$ and acidic in reaction $(6.1 \mathrm{pH})$.The experiment was laid out in spilt plot design with four sowing dates and four varieties of wheat. Four sowing dates viz. $15^{\text {th }}$ November $\left(D_{1}\right), 30^{\text {th }}$ November $\left(D_{2}\right), 15^{\text {th }}$ December $\left(D_{3}\right)$ and $30^{\text {th }}$ December $\left(D_{4}\right)$ were applied in main plot and four varieties viz. GW- $273\left(\mathrm{~V}_{1}\right)$, Lok- $1\left(\mathrm{~V}_{2}\right)$, Sujata $\left(\mathrm{V}_{3}\right)$ and Kanchan $\left(\mathrm{V}_{4}\right)$ in sub-plot and replicated 3 times. The results revealed that sowing on $15^{\text {th }}$ December recorded significantly higher plant height $(36.39 \mathrm{~cm})$ at 30 DAS whereas sowing on $30^{\text {th }}$ December recorded higher plant height $(90.42 \mathrm{~cm})$ at 60 DAS. Sowing on $15^{\text {th }}$ November recorded significantly higher plant height $(103.58 \mathrm{~cm})$ at 90 DAS and $(104.05 \mathrm{~cm})$ at harvest. Varieties Sujata recorded significantly higher plant height $(34.44 \mathrm{~cm})$ at 30 DAS $(92.87 \mathrm{~cm})$ at 60 DAS, $(118.26 \mathrm{~cm})$ at 90 DAS and $(119.12 \mathrm{~cm})$ at harvest. Sowing on $30^{\text {th }}$ December recorded significantly higher number of tillers $\mathrm{m}^{-2}(1000)$ at 30 DAS, whereas sowing on $30^{\text {th }}$ November recorded significantly higher number of tillers $\mathrm{m}^{-2}$ (742.5). Sowing on $15^{\text {th }}$ November recorded relatively higher number of tillers $\mathrm{m}^{-2}(767.5)$ at $90 \mathrm{DAS}$ and $(764.83)$ at harvest. Varieties Sujata recorded significantly higher number of tillers (951.67), (753.75), (764.92) and (761.50) at 30 DAS, 60 DAS, 90 DAS and at harvest respectively. Sowing on $15^{\text {th }}$ November recorded significantly higher duration for CRI (21.42 day), panicle emergence (62.63 day), $50 \%$ flowering (67.58 day), milking (82.67 day) and maturity stage (111.42 day). As compare to sowing on $15^{\text {th }}$ November, duration of wheat crop reduces by 4 day with sown on $30^{\text {th }}$ November, 11 day with sown on $15^{\text {th }}$ December and 19 day with sown on $30^{\text {th }}$ December. Sowing on $15^{\text {th }}$ November recorded significantly higher grain yield $(40.50 \mathrm{q}$ ha ${ }^{1}$ ), straw yield (31.98 q ha ${ }^{-1}$ ), gross return (Rs. ha $\left.{ }^{-1} 61763\right)$, net return (Rs. ha ${ }^{-1} 35498$ ) and B: C ratio (2.35). Varieties GW-273 recorded significantly higher grain yield $\left(38.70 \mathrm{q} \mathrm{ha}^{-1}\right)$, gross return (Rs. ha $\left.{ }^{-1} 59018\right)$, net return (Rs. ha $\left.{ }^{-1} 32903\right)$ and B: C ratio (Rs. 2.26)), whereas Sujata produced significantly higher straw yield (30.42 $\left.\mathrm{q} \mathrm{ha}^{-1}\right)$.

\section{Introduction}

India is second largest producer of wheat (Triticum aestivum L.) in the world after China (134.34 million tonnes) with about $12 \%$ share in total world wheat production. In India, wheat is grown on about 30.60 million hectare area with a production of 98.38 million tonnes and average productivity is
$3216 \mathrm{~kg} \mathrm{ha}^{-1}$ during 2016-17 (Anonymous, 2017) and it is a second most important staple food after rice. In Chhattisgarh wheat occupies 180.38 thousand hectares with a production of 279.59 thousand tonnes and average productivity is $1550 \mathrm{~kg} \mathrm{ha}^{-1}$ during 2017-18 (Anonymous, 2018). The yield and quality of wheat grain is influenced by several factors such as soil, climate, variety, sowing 
method, sowing time, sowing depth, seed rate, water \& nutrient management, weed, insect \& disease management, harvesting time and other agronomic practices etc.

The seeding or planting time of various field crops is governed not only by the environmental requirements for the crop but also necessary for avoiding the ravages of diseases and insect pests. Proper time of sowing helps cultivars to express its growth patterns to its full extent in a diverse setting of environmental dynamic beside genotype environmental interaction. Other environmental factors like temperature, rainfall, humidity, solar radiation and soil types also contribute much towards the variety performance under a given locality. In addition during too early sowing the temperature is above the optimum which deals to irregular germination caused by frequent death of embryos and decomposition of endosperm due to bacteria or fungi (Paul, 1992). Late planting results in poor tillering and more chances of winter injury (Joshi et al., 1992). Wheat like other cool season generally is seeded early in the season to permit maximum growth and development toward maturity before the advent of hot weather, drought and diseases.

Proper sowing time and varietal selection could be responsible for higher production. Appropriate sowing time of various field crops results in higher economic yield without involving extra cost as it helps varieties to express their full growth potential. The sowing time of wheat crop plays a pivotal role in a country like India, where climatic conditions vary throughout the country and delay in sowing decreases wheat grain yield by 58.2 percent (Muhammad et al., 2010). Selection of optimum sowing date for a particular region vital to obtain high yield due variation among the weather conditions. At tillering stage, optimum sowing time could produce good crop growth that increases the cold tolerance. Time of sowing is one of the most important factors which govern the crop phonological development and total biomass production along with efficient conversion of biomass into economic yield. Both early and late sowing of wheat causes reduction in length of spike and number of kernel per spike. Delayed sowing of wheat crop is exposed to sub- optimal temperatures at establishment and supra-optimal temperatures at reproductive phases resulting into reduction of not only crop duration but also the yield (Sardana et al., 1999). Cultivation of wheat in Bastar Plateau zone of Chhattisgarh mostly under rice- wheat cropping system. In this cropping system, sowing of wheat becoming late due to late harvesting of rice, and high moisture content in field. Temperature stress after anthesis cause drastic effect on grain yield production. Suitable varieties, timely sowing \& irrigation, proper weed, insect and disease management etc. can increase production of wheat in the region. Among all practices sowing time and varieties majorly affect yield of wheat. Keeping in view the present study was conducted with aim to optimize sowing time for getting higher yield of wheat varieties under NARP zone- Bastar Plateau Zone of Chhattisgarh.

\section{Materials and Methods}

A field experiment was conducted during the Rabi season of 2016-17, at the Instructional Farm, Shaheed Gundadhoor College of Agriculture \& Research Station, Kumhrawand, Jagdalpur District- Bastar (Chhattisgarh). The soil of experimental site was sandy loam; it was low in organic carbon $(0.41 \%)$ and available nitrogen $\left(228.90 \mathrm{~kg} \mathrm{ha}^{-}\right.$ $\left.{ }^{1}\right)$ and medium in available phosphorus (12.26 $\left.\mathrm{kg} \mathrm{ha}{ }^{-1}\right)$ and potassium (286.25 $\left.\mathrm{kg} \mathrm{ha}^{-1}\right)$ and acidic in reaction $(6.1 \mathrm{pH})$. The experiment was laid out in spilt plot design with four sowing dates and four varieties of wheat. Four 
sowing dates viz. $15^{\text {th }}$ November $\left(\mathrm{D}_{1}\right), 30^{\text {th }}$ November $\left(\mathrm{D}_{2}\right), 15^{\text {th }}$ December $\left(\mathrm{D}_{3}\right)$ and $30^{\text {th }}$ December $\left(\mathrm{D}_{4}\right)$ were applied in main plot and four varieties viz. GW- $273\left(\mathrm{~V}_{1}\right)$, Lok- $1\left(\mathrm{~V}_{2}\right)$, Sujata $\left(\mathrm{V}_{3}\right)$ and Kanchan $\left(\mathrm{V}_{4}\right)$ in sub-plot and replicated 3 times. Recommended dose of nutrients was 120:60:40 $\mathrm{kg} \mathrm{N}: \mathrm{P}: \mathrm{K} \mathrm{ha}^{-1}$. Entire quantity of phosphorus \& potassium was applied before sowing. Nitrogen applied in three splits i.e. $50 \%$ as a basal, $25 \%$ at tillering and $25 \%$ at panicle emergence stage. Experiment was conducted under irrigated condition and irrigated 5 times in different crop stages. Crop seed sown on different dates with a row spacing of $20 \mathrm{~cm}$ and seed rate was $125 \mathrm{~kg} \mathrm{ha}^{-1}$. Herbicide pendimethalin 37.8 CS applied @ $0.660 \mathrm{~kg} \mathrm{ha}^{-1}$ in $3^{\text {rd }}$ day of sowing. The average maximum and minimum temperature varied between $24.26^{\circ} \mathrm{c}-39.2^{\circ} \mathrm{c}$ and $9.33^{\circ} \mathrm{c}-17.50^{\circ} \mathrm{c}$ respectively.

The plant height was measured randomly of 5 plants of each plot in centimeter from ground surface up to the tip of awn. The number of tillers counted from $0.25 \mathrm{~m}^{2}$ area by placing a quadrate of $0.5 \mathrm{~m} \times 0.5 \mathrm{~m}$ randomly at 4 places in each plot and then number of tillers $\mathrm{m}^{-2}$ worked out. Occurrence of crop stages recorded by visited every day at experimental site. The harvest index was calculated by dividing the grain yield with biological yield (grain + straw yield) and multiplied by 100 .

Harvest Index $(\%)=\frac{\text { Grain yield }(q / h a)}{\text { Biological yield }(q / h a)}$ X100

\section{Results and Discussion}

\section{Plant height}

Average plant height increased progressively with increase in the age of the crop. The plant gained height at relatively slower rate between 90 DAS to at harvest and accelerated between 30 to 90 DAS. The Plant height of wheat influenced significantly due to sowing dates and varieties (Table 1). Among the sowing date treatments, sowing on $15^{\text {th }}$ December recorded significantly higher plant height $(36.39 \mathrm{~cm})$ at 30 DAS followed by $30^{\text {th }}$ December $(33.12 \mathrm{~cm})$, while sowing on $30^{\text {th }}$ December recorded higher plant height $(90.42$ $\mathrm{cm})$ at 60 DAS followed by $15^{\text {th }}$ December $(86.75 \mathrm{~cm})$. Sowing on $15^{\text {th }}$ November recorded significantly higher plant height $(103.58 \mathrm{~cm})$ at 90 DAS and $(104.05 \mathrm{~cm})$ at harvest followed by sowing on $30^{\text {th }}$ November $(100.68 \mathrm{~cm})$ and $(101.63 \mathrm{~cm})$ respectively

Among the varieties Sujata recorded significantly higher plant height $(34.44 \mathrm{~cm})$ at 30 DAS, $(92.87 \mathrm{~cm})$ at 60 DAS, $(118.26 \mathrm{~cm})$ at 90 DAS and $(119.12 \mathrm{~cm})$ at harvest followed by GW-273 $(33.14 \mathrm{~cm})$ at 15 DAS, $(82.24 \mathrm{~cm})$ at 60 DAS, $(93.57 \mathrm{~cm})$ at 90 DAS and $(94.73 \mathrm{~cm})$ at harvest. In case of varieties difference in plant height may be due to their genetic characters. Muhammad et al., 2015 conducted experiment in Bahawalpur, Pakistan recorded significantly higher plant height $(102 \mathrm{~cm})$ of wheat with sown on $11^{\text {th }}$ November.

\section{Number of tillers}

The number of tillers decreasing with increasing the crop age up to 60 DAS and increasing with increase the crop age up to 90 DAS, but the number of tillers at maturity slightly reduced. The number of tillers of wheat influenced significantly due to varieties and sowing dates at 30 DAS and 60 DAS, whereas number of tillers did not influenced significantly due to sowing dates at 90 DAS and at harvest (Table 1). Among the sowing dates, sowing on $30^{\text {th }}$ December recorded significantly higher number of tillers $\left(1000 \mathrm{~m}^{-}\right.$ $\left.{ }^{2}\right)$ at 30 DAS followed by sowing on $15^{\text {th }}$ December $\left(821.25 \mathrm{~m}^{-2}\right)$, while sowing on $30^{\text {th }}$ November recorded significantly higher number of tillers $\left(742.5 \mathrm{~m}^{-2}\right)$ followed by sowing on $15^{\text {th }}$ December $\left(723.75 \mathrm{~m}^{-2}\right)$. 
Sowing on $15^{\text {th }}$ November recorded relatively higher number of tillers $\left(767.5 \mathrm{~m}^{-2}\right)$ at 90 DAS and $\left(764.83 \mathrm{~m}^{-2}\right)$ at harvest, followed by sowing on $30^{\text {th }}$ November $\left(748.67 \mathrm{~m}^{-2}\right)$ and $\left(742.17 \mathrm{~m}^{-2}\right)$ respectively.

Number of tillers of wheat varieties influenced significantly at all the stages of crop growth. Among the varieties Sujata recorded significantly higher number of tillers $\mathrm{m}^{-2}$ (951.67), (753.75), (764.92) and (761.50) followed by Lok-1 (889.17), (697.5), (758.92) and (752.50) at 30 DAS, 60 DAS, 90 DAS and at harvest respectively. In case of varieties difference in number of tillers may be due to their genetic characters. Muhammad et al., 2015 in Pakistan recorded significantly higher number of tillers $\mathrm{m}^{-2}$ (421) of wheat with sown on $11^{\text {th }}$ November

\section{Days to occurrence of crop growth stages}

The days to occurrence of crop growth stages influenced significantly due to sowing dates and varieties. Days to occurrence of CRI, panicle emergence, $50 \%$ flowering, milking and maturity decreased as sowing was delayed from $15^{\text {th }}$ November to $30^{\text {th }}$ December (Table 2). Among the sowing dates, sowing on $15^{\text {th }}$ November recorded significantly higher duration for crown root initiation (21.42 day), panicle emergence (62.63 day), $50 \%$ flowering (67.58 day), milking (82.67 day) and maturity stage (111.42 day) followed by sowing on $30^{\text {th }}$ November for crown root initiation (20.92 day), panicle emergence (59.75 day), $50 \%$ flowering (64.92 day), milking (80.50 day) and maturity stage (107.75 day). As compare to sowing on $15^{\text {th }}$ November, duration of wheat crop reduces by 4 day with sown on $30^{\text {th }}$ November, 11 day with sown on $15^{\text {th }}$ December and 19 day with sown on $30^{\text {th }}$ December. Variety Sujata taken significantly more time for CRI (21 day), panicle emergence (62.75 day), 50\% flowering (69.25 day), milking (83.33 day) and maturity (110.83 day) followed by Kanchan for CRI (20.42 day), panicle emergence (57.92 day), $50 \%$ flowering (63.33 day), milking (78.67 day) and maturity stage (101.33 day). Variety Lok-1 taken lowest duration for CRI (19.67 day), panicle emergence (54.50 day), $50 \%$ flowering (59 day), milking (74.42 day) and maturity stage (100.75 day).

In case of varieties difference in days to occurrence of crop growth stages may be due to their genetic characters. Wajid et al., 2006 in Pesawar, Pakistan reported that days to heading decreased as planting were delayed from $1^{\text {st }}$ November to $16^{\text {th }}$ January. Similarly in Punjab, Pakistan (Muhammad et al., 2015) recorded that days to booting, heading, anthesis and matutrity decreased as sowing was delayed from $1^{\text {st }}$ November to $21^{\text {st }}$ December.

\section{Grain and straw yield and harvest index}

The grain and straw yield significantly influenced due to sowing dates and varieties, (Table 3). Among the sowing dates sowing on $15^{\text {th }}$ November recorded significantly higher grain yield $\left(40.50 \mathrm{q} \mathrm{ha}^{-1}\right)$ and straw yield $\left(31.98 \mathrm{q} \mathrm{ha}^{-1}\right)$ followed by sowing on $30^{\text {th }}$ November recorded grain yield $\left(36.17 \mathrm{q} \mathrm{ha}^{-1}\right)$ and straw yield (30.38 q ha $\left.{ }^{-1}\right)$, whereas harvest index did not influenced significantly due to sowing dates.

Among the varieties GW-273 produce significantly higher grain yield $\left(38.70 \mathrm{q} \mathrm{ha}^{-1}\right)$ followed by Lok-1 (36.0 q ha ${ }^{-1}$ ), Kanchan $\left(32.30 \mathrm{q} \mathrm{ha}^{-1}\right)$, and Sujata $\left(29.90 \mathrm{q} \mathrm{ha}^{-1}\right)$. Variety Sujata produce significantly higher straw yield (30.42 $\mathrm{q} \mathrm{ha}^{-1}$ ) followed by Lok-1 (30.22 q ha $\left.{ }^{-1}\right)$, GW-273 (26.49 q ha ${ }^{-1}$ ) and Kanchan (25.08 q ha $\left.{ }^{-1}\right)$. Harvest index significantly higher under variety GW-273 $(60.10 \%)$ followed by Kanchan (56.47\%), Lok-1 (54.33\%) and Sujata (49.53\%). 
Table.1 Plant height and number of tillers at different stages of wheat varieties as influenced by sowing dates

\begin{tabular}{|c|c|c|c|c|c|c|c|c|}
\hline \multirow[t]{2}{*}{ Treatment } & \multicolumn{4}{|c|}{ Plant height (cm) } & \multicolumn{4}{|c|}{ Number of tillers $\left(\mathrm{m}^{2}\right)$} \\
\hline & $\begin{array}{c}30 \\
\text { DAS }\end{array}$ & $\begin{array}{c}60 \\
\text { DAS }\end{array}$ & $\begin{array}{c}90 \\
\text { DAS }\end{array}$ & $\begin{array}{c}\text { At } \\
\text { harvest }\end{array}$ & 30 DAS & $\begin{array}{c}60 \\
\text { DAS }\end{array}$ & $\begin{array}{c}90 \\
\text { DAS }\end{array}$ & $\begin{array}{c}\text { At } \\
\text { harvest }\end{array}$ \\
\hline \multicolumn{9}{|l|}{ Sowing dates } \\
\hline $15^{\text {th }}$ November & 28.95 & 83.12 & 103.58 & 104.05 & 817.50 & 582.50 & 767.50 & 764.83 \\
\hline $30^{\text {th }}$ November & 32.91 & 76.18 & 100.68 & 101.63 & 820.00 & 742.50 & 748.67 & 742.17 \\
\hline $15^{\text {th }}$ December & 36.39 & 86.75 & 94.97 & 95.62 & 821.25 & 723.75 & 725.33 & 718.92 \\
\hline $30^{\text {th }}$ December & 33.12 & 90.42 & 92.54 & 93.16 & 1000.00 & 718.75 & 720.00 & 714.42 \\
\hline SEm \pm & 1.35 & 2.73 & 2.09 & 2.05 & 16.34 & 28.33 & 33.12 & 33.86 \\
\hline $\mathrm{CD}(\mathrm{P}=0.05)$ & 4.68 & 9.44 & 7.24 & 7.08 & 56.55 & 98.03 & NS & NS \\
\hline \multicolumn{9}{|l|}{ Varieties } \\
\hline GW-273 & 33.14 & 82.24 & 93.57 & 94.73 & 797.08 & 667.50 & 735.83 & 730.25 \\
\hline Lok-1 & 31.28 & 80.43 & 88.00 & 88.53 & 889.17 & 697.50 & 758.92 & 752.50 \\
\hline Sujata & 34.44 & 92.87 & 118.26 & 119.12 & 951.67 & 753.75 & 764.92 & 761.50 \\
\hline Kanchan & 32.50 & 80.93 & 93.08 & 93.93 & 820.83 & 648.75 & 701.83 & 696.08 \\
\hline SEm \pm & 0.48 & 1.15 & 0.74 & 0.77 & 25.47 & 14.76 & 12.78 & 13.03 \\
\hline $\mathrm{CD}(\mathrm{P}=0.05)$ & 1.41 & 3.36 & 2.17 & 2.26 & 74.34 & 43.09 & 37.29 & 38.04 \\
\hline
\end{tabular}

DAS- Days After Sowing

Table.2 Occurrence of crop stages of wheat varieties as influenced by sowing dates

\begin{tabular}{|c|c|c|c|c|c|}
\hline \multirow[t]{2}{*}{ Treatment } & \multicolumn{5}{|c|}{ Occurrence of crop stage (Day) } \\
\hline & CRI & $\begin{array}{c}\text { Panicle } \\
\text { emergence }\end{array}$ & $\begin{array}{c}50 \% \\
\text { Flowering }\end{array}$ & Milking & Maturity \\
\hline \multicolumn{6}{|l|}{ Sowing dates } \\
\hline $15^{\text {th }}$ November & 21.42 & 62.83 & 67.58 & 82.67 & 111.42 \\
\hline $30^{\text {th }}$ November & 20.92 & 59.75 & 64.92 & 80.50 & 107.75 \\
\hline $15^{\text {th }}$ December & 19.92 & 56.42 & 62.00 & 76.92 & 100.67 \\
\hline $30^{\text {th }}$ December & 19.17 & 53.08 & 58.92 & 72.33 & 92.92 \\
\hline SEm \pm & 0.25 & 0.42 & 0.36 & 0.46 & 1.03 \\
\hline $\mathrm{CD}(\mathrm{P}=\mathbf{0 . 0 5})$ & 0.88 & 1.46 & 1.25 & 1.60 & 3.55 \\
\hline \multicolumn{6}{|l|}{ Varieties } \\
\hline GW-273 & 20.33 & 56.92 & 61.83 & 76.00 & 100.83 \\
\hline Lok-1 & 19.67 & 54.50 & 59.00 & 74.42 & 100.75 \\
\hline Sujata & 21.00 & 62.75 & 69.25 & 83.33 & 110.83 \\
\hline Kanchan & 20.42 & 57.92 & 63.33 & 78.67 & 101.33 \\
\hline SEm \pm & 0.10 & 0.29 & 0.16 & 0.15 & 0.35 \\
\hline $\mathrm{CD}(\mathrm{P}=0.05)$ & 0.29 & 0.87 & 0.47 & 0.45 & 1.01 \\
\hline
\end{tabular}


Table.3 Grain and straw yield, economics of wheat as influenced by sowing dates and varieties

\begin{tabular}{|c|c|c|c|c|c|c|c|}
\hline Treatment & $\begin{array}{c}\text { Grain } \\
\text { yield } \\
\left(\mathbf{q} \mathbf{h a}^{-1}\right)\end{array}$ & $\begin{array}{c}\text { Straw } \\
\text { yield } \\
\left(\mathbf{q} \mathbf{h a}^{-1}\right)\end{array}$ & $\begin{array}{l}\text { Harvest } \\
\text { index } \\
(\%)\end{array}$ & $\begin{array}{c}\text { Cost of } \\
\text { cultivation } \\
\left(\text { Rs. ha }{ }^{-1}\right)\end{array}$ & $\begin{array}{c}\text { Gross } \\
\text { return } \\
\left(\text { Rs. ha }{ }^{-1}\right)\end{array}$ & $\begin{array}{c}\text { Net } \\
\text { return } \\
\left(\text { Rs. } \text { ha }^{-1}\right)\end{array}$ & $\begin{array}{l}\text { B: C } \\
\text { ratio }\end{array}$ \\
\hline \multicolumn{8}{|l|}{ Sowing dates } \\
\hline $15^{\text {th }}$ November & 40.50 & 31.98 & 55.88 & 26265 & 61763 & 35498 & 2.35 \\
\hline $30^{\text {th }}$ November & 36.17 & 30.38 & 54.35 & 26265 & 55159 & 28894 & 2.10 \\
\hline $15^{\text {th }}$ December & 33.65 & 27.91 & 54.96 & 26265 & 51316 & 25051 & 1.95 \\
\hline $30^{\text {th }}$ December & 26.60 & 21.93 & 54.75 & 26265 & 40565 & 14300 & 1.54 \\
\hline SEm \pm & 2.63 & 2.01 & 1.74 & - & - & - & - \\
\hline $\mathrm{CD}(\mathrm{P}=0.05)$ & 9.09 & 6.96 & NS & - & - & - & - \\
\hline \multicolumn{8}{|l|}{ Varieties } \\
\hline GW-273 & 38.70 & 26.49 & 60.10 & 26115 & 59018 & 32903 & 2.26 \\
\hline Lok-1 & 36.00 & 30.22 & 54.33 & 26115 & 54900 & 28785 & 2.10 \\
\hline Sujata & 29.90 & 30.42 & 49.53 & 26715 & 54568 & 27853 & 2.04 \\
\hline Kanchan & 32.30 & 25.08 & 56.47 & 26115 & 49258 & 23143 & 1.89 \\
\hline SEm \pm & 1.01 & 1.41 & 1.55 & - & - & - & - \\
\hline $\mathrm{CD}(\mathrm{P}=0.05)$ & 2.94 & 4.11 & 4.52 & - & - & - & - \\
\hline
\end{tabular}

Price of Seed: Rs. $2600 \mathrm{q}^{-1}$ (GW-273, Lok-1 \& Kanchan) and $3200 \mathrm{q}^{-1}$ (Sujata)

Price of sold grain: Rs. $1525 \mathrm{q}^{-1}$ (GW-273, Lok-1 \& Kanchan) and $1825 \mathrm{q}^{-1}$ (Sujata)

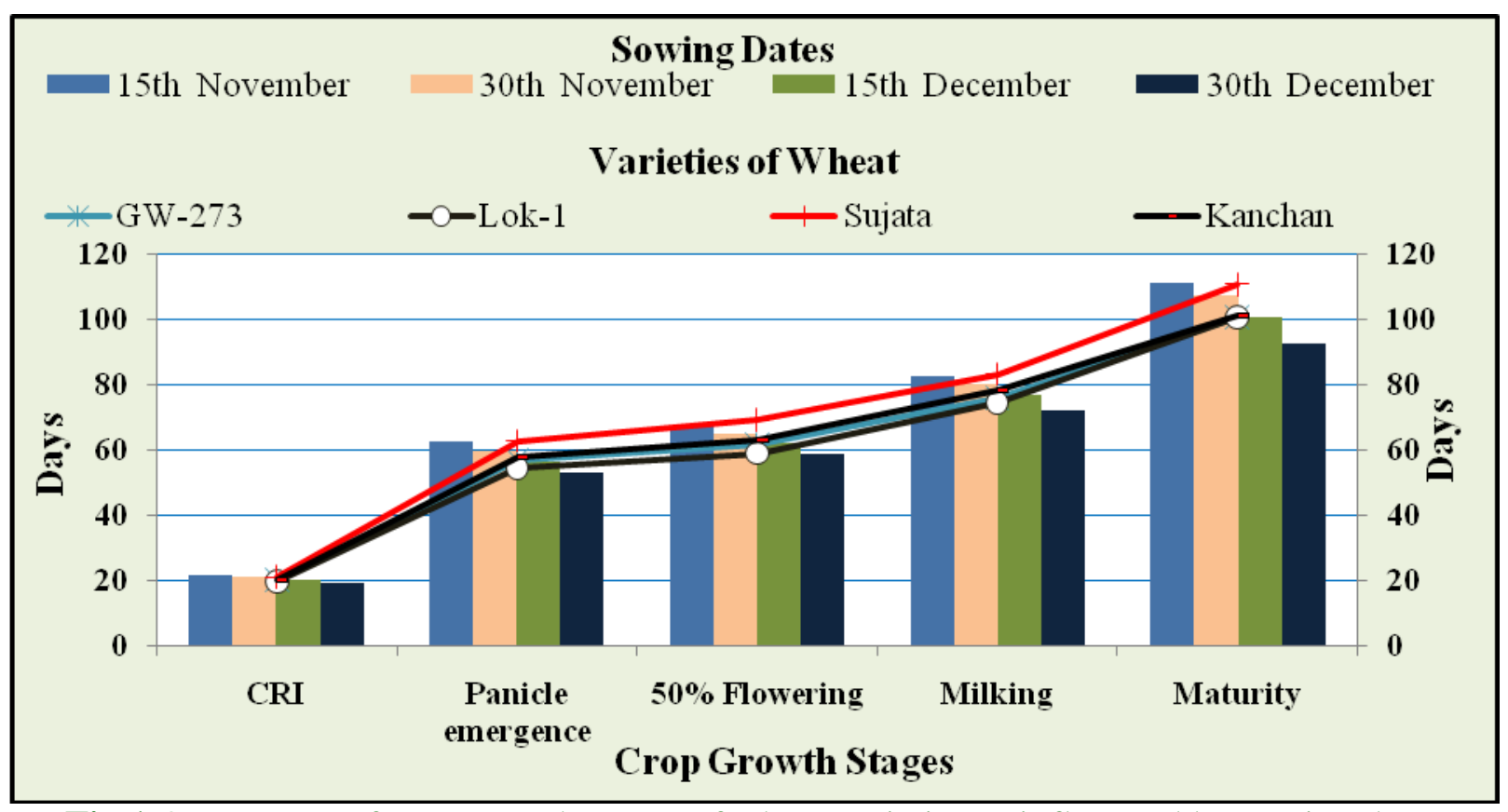

Fig.1 Occurrence of crop growth stages of wheat varieties as influenced by sowing dates 


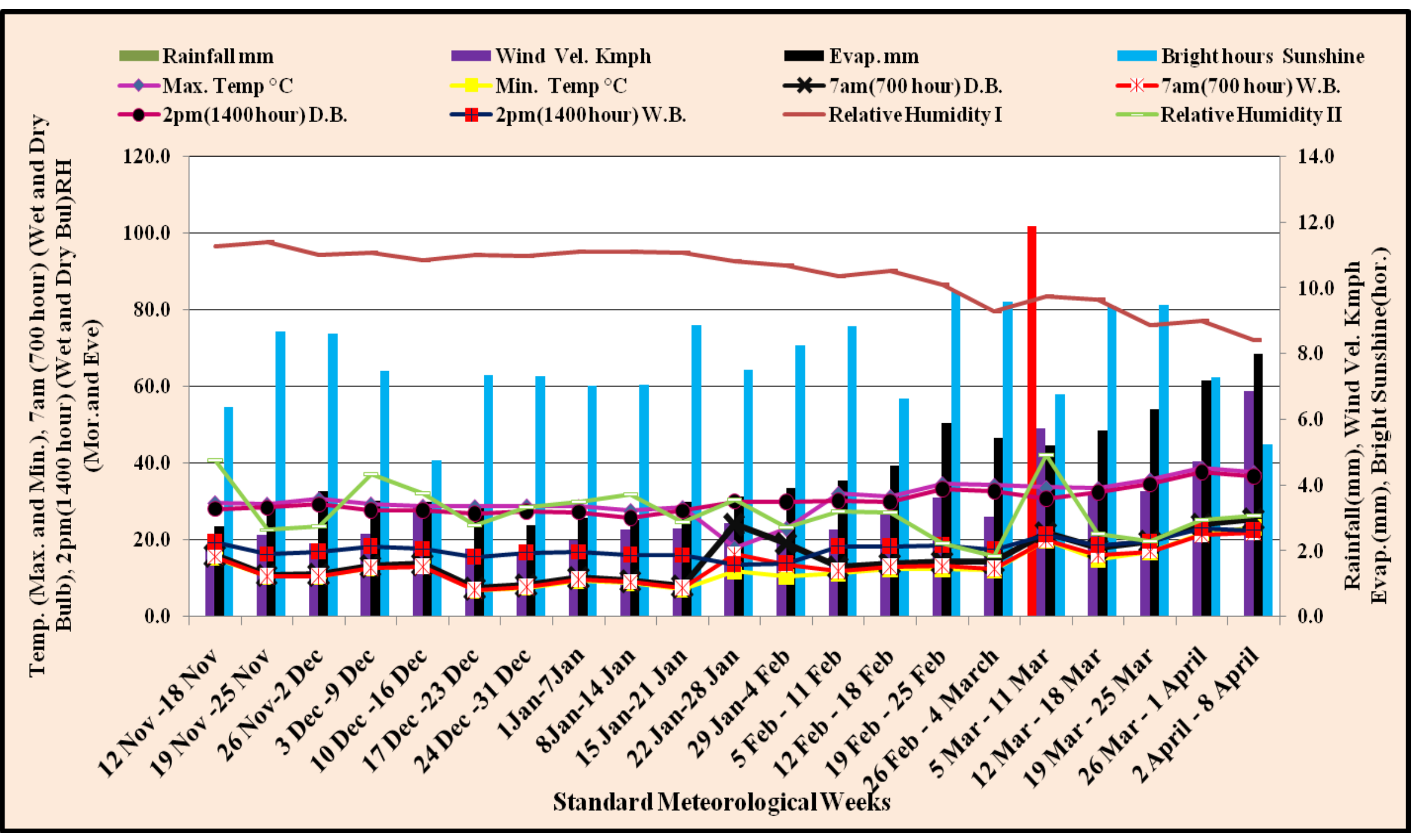

Fig.2 Weekly meteorological data prevailing during crop growth period (Rabi, 2016-17) 
Higher grain yield of wheat variety GW-273 was mainly attributed due to higher number of effective tillers and other yield attributing characters. In case of varieties difference in grain and straw yield may be due to their genetic characters.

In Raipur, Chhattisgarh Chetal Lal, 2019 recorded that the varieties Sujata, Kanchan and GW-273 produced maximum grain yield (3837.5 kg/ha, $3670.0 \mathrm{~kg} / \mathrm{ha}$ and $3643.3 \mathrm{~kg} / \mathrm{ha}$ respectively), when sown on 06 December. Sardana et al., 2002 recorded that delay in sowing from 15 November to 15 December decreased the wheat grain yield by 32.6 and $27.4 \%$ in 1997-98 and 1998-99 respectively at Punjab. Mukherjee et al., 2018 conducted experiment at Jagdalpur, Chhattisgarh and recorded that $4250 \mathrm{~kg} \mathrm{ha}^{-1}$ grain yield of wheat with sown on $1^{\text {st }}$ December, whereas varieties not influenced significantly.

\section{Economics of production of wheat varieties}

Effect of different treatments cannot be assessed without the gross and net return from that treatment. The economics of different treatments have been presented in Table 3 . Among the sowing dates sowing on $15^{\text {th }}$ November recorded the highest gross return (Rs. ha ${ }^{-1}$ 61763), net return (Rs. ha ${ }^{-1}$ 35498) and $\mathrm{B}$ : $\mathrm{C}$ ratio (2.35) followed by sowing on $30^{\text {th }}$ November, gross return (Rs. ha ${ }^{-1} 55159$ ), net return (Rs. ha ${ }^{-1}$ 28894) and B: C ratio (2.10). Among the varieties, GW-273 recorded highest gross return (Rs. ha ${ }^{-1}$ 59018), net return (Rs. ha ${ }^{-1}$ 32903) and B: C ratio (Rs. 2.26) followed by Lok-1 with gross return (Rs. ha ${ }^{-1}$ 54900), net return (Rs. ha ${ }^{-1}$ 28785) and B: C ratio (Rs. 2.10).

On the basis of experimental findings, it is concluded that wheat should be sown from $15^{\text {th }}$ to $30^{\text {th }}$ November for obtaining higher yield of grain and straw and gross \& net return. Wheat varieties GW-273 and Lok-1 should be sown for obtaining higher grain yield and gross \& net return in the Bastar Plateau Zone of Chhattisgarh.

\section{References}

Anonymous. 2017. Department of Agriculture, Cooperation \& Farmers Welfare, Government of India, New Delhi.

Anonymous. 2018. Directorate of Agriculture. Government of Chhattisgarh, Raipur.

Chetan Lal. 2019. Yield attributes and yield of various varieties of wheat under different dates of sowing in rice based cropping system in Chhattisgarh. Journal of Pharmacognosy and Phytochemistry. 8(1): 1066-1068.

Joshi A. K., Rai B. and Singh M. P. 1992. Technology for late sown weat in Eastern Uttar Pradesh. Indian Farming.42:15-15

Muhammad Anjum Ali, Mushtaq Ali, Muhammad Sattar and Liaqat Ali.2010. Sowing dates effects on yield of different wheat varieties. J. Agric. Research. 48 (2): 157-162.

Muhammad Zahid Mumtaz, Muhammad Aslam, Hafiz Muhammad Nasrullah, $\mathrm{Mu}$ hammad Aktar and Basharat Ali. 2015. Effect of various sowing dates on growth, yield and yield components of different wheat genotypes. American Eurasian J. Agric. \& Environ.Sci., 15 (11): 2230-2234.

Mukherjee D., Kumar M., Das G.K. and Mukherjee S.C..2018. Effect of weather parameter on growth and yield of wheat under different growing environment in bastar plateau zone. International Journal of Chemical Studies. 6 (6): 1080-1085

Paul S.R.1992. Efeect of pre sowing treatments, seed rates, fertility levels and surface soil competition on growth and yield of late sown rainfed wheat in 
Assam. Agric. Res. 13: 410-411.

Sardana V., Sharma S.K., Randhawa A.S.. 1999. Performance of wheat cultivars under different sowing dates and level of nitrogen under rainfed conditions. Annals Agric. Res. 20, 60-63.

Sardana Virender, Sharma S.K., Randhawa A.S..2002. Performance of wheat (Triticum aestivum) varieties under different sowing dates and nitrogen levels in the submontane region of
Punjab. Indian Journal of Agronomy. 47 (3): 372-377.

Wajid Ali Shah, Jehan Bakht, Tehseen Ullah, Abdul Wahab Khan, Muhammad Zubair and Abdul Aziz Khakwani. 2006. Effect of Sowing Dates on the Yield and Yield Components of Different Wheat Varieties. Journal of Agronomy, 5: 106-110.

\section{How to cite this article:}

Anil Kumar Netam, Upendra Kumar Nag and Chainu Ram Netam. 2020. Growth and Yield of Wheat (Triticum aestivum L.) Varieties as Influenced by Different Sowing Dates under Bastar Plateau Zone of Chhattisgarh. Int.J.Curr.Microbiol.App.Sci. 9(06): 2161-2169.

doi: https://doi.org/10.20546/ijcmas.2020.906.264 